\title{
Article \\ Batch and Flow Nitroaldol Synthesis Catalysed by Granulicella tundricola Hydroxynitrile Lyase Immobilised on Celite R-633
}

\author{
José Coloma ${ }^{1,2}{ }^{\text {, Lidwien Teeuwisse }}{ }^{1}$, Muhammad Afendi ${ }^{1}$, Peter-Leon Hagedoorn ${ }^{1}$ (D) and Ulf Hanefeld ${ }^{1, *(D)}$ \\ 1 Biokatalyse, Afdeling Biotechnologie, Technische Universiteit Delft, Van der Maasweg 9, \\ 2629 HZ Delft, The Netherlands; J.L.ColomaHurel@tudelft.nl (J.C.); L.C.Teeuwisse@student.tudelft.nl (L.T.); \\ MuhammadFarhanbinMuhammadAfendi@student.tudelft.nl (M.A.); P.L.Hagedoorn@tudelft.nl (P.-L.H.) \\ 2 Facultad de Ciencias Agropecuarias, Ingeniería Agroindustrial, Universidad Laica Eloy Alfaro de Manabí, \\ Avenida Circunvalación s/n, Manta 13-05-2732, Ecuador \\ * Correspondence: u.hanefeld@tudelft.nl; Tel.: +31-15-278-9304
}

check for updates

Citation: Coloma, J.; Teeuwisse, L.; Afendi, M.; Hagedoorn, P.-L.; Hanefeld, U. Batch and Flow Nitroaldol Synthesis Catalysed by Granulicella tundricola Hydroxynitrile Lyase Immobilised on Celite R-633. Catalysts 2022, 12, 161. https:// doi.org/10.3390/catal12020161

Academic Editor: Roberto

Fernandez-Lafuente

Received: 7 January 2022

Accepted: 25 January 2022

Published: 27 January 2022

Publisher's Note: MDPI stays neutral with regard to jurisdictional claims in published maps and institutional affiliations.

Copyright: (C) 2022 by the authors. Licensee MDPI, Basel, Switzerland. This article is an open access article distributed under the terms and conditions of the Creative Commons Attribution (CC BY) license (https:// creativecommons.org/licenses/by/ $4.0 /)$.

\begin{abstract}
Granulicella tundricola hydroxynitrile lyase (GtHNL) catalyses the synthesis of chiral (R)cyanohydrins and (R)- $\beta$-nitro alcohols. The triple variant GtHNL-A40H/V42T/Q110H (GtHNL-3V) was immobilised on Celite R-633 and used in monophasic MTBE saturated with $100 \mathrm{mM} \mathrm{KPi}$ buffer pH 7 for the synthesis of (R)-2-nitro-1-phenylethanol (NPE) in batch and continuous flow systems. Nitromethane was used as a nucleophile. A total of $82 \%$ of $(R)-\mathrm{NPE}$ and excellent enantioselectivity $(>99 \%)$ were achieved in the batch system after $24 \mathrm{~h}$ of reaction time. GtHNL-3V on Celite R-633 was successfully recycled five times. During more recycling steps a significant decrease in yield was observed while the enantioselectivity remained excellent over eight cycles. The use of a flow system enabled the continuous synthesis of $(R)$-NPE. A total of $15 \%$ formation of $(R)$-NPE was reached using a flow rate of $0.1 \mathrm{~mL} \mathrm{~min}^{-1}$; unfortunately, the enzyme was not stable, and the yield decreased to $4 \%$ after $4 \mathrm{~h}$ on stream. A similar yield was observed during $15 \mathrm{~h}$ at a rate of $0.01 \mathrm{~mL} \mathrm{~min}^{-1}$. Surprisingly the use of a continuous flow system did not facilitate the process intensification. In fact, the batch system displayed a space-time-yield (STY $/ \mathrm{mg}_{\text {enzyme }}$ ) of $0.10 \mathrm{~g} \mathrm{~L}^{-1} \mathrm{~h}^{-1} \mathrm{mg}_{\text {enzyme }}{ }^{-1}$ whereas the flow system displayed 0.02 and $0.003 \mathrm{~g} \mathrm{~L}^{-1} \mathrm{~h}^{-1} \mathrm{mg}_{\text {enzyme }}{ }^{-1}$ at 0.1 and $0.01 \mathrm{~mL} \mathrm{~min}^{-1}$, respectively. In general, the addition of $1 \mathrm{M}$ nitromethane potentially changed the polarity of the reaction mixture affecting the stability of Celite-GtHNL-3V. The nature of the batch system maintained the reaction conditions better than the flow system. The higher yield and productivity observed for the batch system show that it is a superior system for the synthesis of $(R)$-NPE compared with the flow approach.
\end{abstract}

Keywords: Granulicella tundricola; hydroxynitrile lyase; celite; immobilisation; batch; continuous flow; nitroaldol reaction; $(R)-\mathrm{NPE}$

\section{Introduction}

Chiral $\beta$-nitro alcohols are compounds containing two versatile functional groups, a hydroxyl and a nitro group, attached to adjacent carbon centres of which either one or both are asymmetric. These compounds are precursors of chiral $\beta$-amino alcohols, which are important chiral building blocks for the synthesis of bioactive compounds used as pharmaceutical ingredients such as bestatin, ephedrine, norephedrine, and sphingosine [1,2]. The nitroaldol synthesis (Henry reaction) of $\beta$-nitro alcohols is base catalysed and many bases have been evaluated. Unfortunately, the unwanted side reactions such as aldol reactions, Cannizzaro disproportionation, and water elimination catalysed by these strong bases hamper their application [3]. Biocatalysis is an alternative method for producing $\beta$-nitro alcohols with high selectivity under mild reaction conditions. Six biocatalytic approaches [4-24] have been described as recently reviewed [1]. Of these, the HNL catalysed Henry reaction is particularly attractive as a new carbon-carbon bond and a stereocentre is 
established simultaneously. This promiscuous HNL activity is based on the similar $\mathrm{pK}_{\mathrm{a}}$ value of hydrogen cyanide $\left(\mathrm{pK}_{\mathrm{a}}=9.21\right)$ and nitromethane $\left(\mathrm{pK}_{\mathrm{a}}=10.2\right)($ Scheme 1$)$.

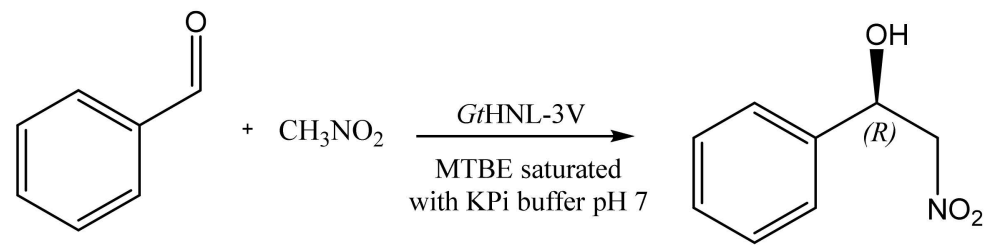

Scheme 1. Nitro aldol synthesis of (R)-2-nitro-1-phenylethanol catalysed by GtHNL-3V.

The synthesis of (R)-2-nitro-1-phenylethanol catalysed by GtHNL-3V, a more active and stable variant compared with the wild-type enzyme, was reported using a biphasic system in a batch process [12]. Long reaction times $(24 \mathrm{~h})$ were needed to achieve $72.8 \%$ of conversion and $94.5 \%$ of enantiomeric excess. Flow chemistry is an important tool for process intensification and has been reported to reduce reaction times concomitantly improving enantioselectivities by suppressing undesired side reactions. Additionally, it enhances safety and among others reduces reaction volumes [25-32]. At the same time, it requires the enzymes to be immobilised, which often improves enzyme stability. Celite is an environmentally friendly, food grade carrier that has been used for the immobilisation of several HNLs with good results [33-35]. This cheap hydrophilic carrier has the ability to bind water efficiently. This enables a local aqueous environment around the enzyme and avoids the use of chemicals during the enzyme immobilisation which might affect the enzyme stability [36]. Indeed, the successful immobilisation of GtHNL-3V on Celite R-633 for the synthesis of $(R)$-mandelonitrile in batch and flow systems has been reported [37]. Good conversion, excellent enantioselectivity, and high stability were achieved in both systems. In addition, the continuous flow system enabled an important increase in the space-time-yield (65 times) compared with the batch system.

Herein, we aim to evaluate the GtHNL-3V catalysed nitroaldol reaction for the synthesis of (R)-2-nitro-1-phenylethanol in batch and flow systems. For this, GtHNL-3V was immobilised on Celite R-633. Monophasic MTBE saturated with $100 \mathrm{mM} \mathrm{KPi}$ buffer pH 7 was employed as reaction medium. The activity, stability and productivity of batch and flow systems were investigated.

\section{Results and Discussion}

GtHNL-3V was successfully overexpressed in E. coli Bl21(DE3) and purified by a heat treatment. It displayed a specific activity of $2.2 \pm 0.05 \mathrm{U} \mathrm{mg}^{-1}$ for the cleavage of racmandelonitrile into benzaldehyde and hydrogen cyanide. The enzyme was immobilised on Celite R-633 by adsorption of an enzyme solution in $100 \mathrm{mM}$ potassium phosphate buffer pH 7 as described earlier [37]. The synthesis of (R)-NPE (Scheme 1) was performed with MTBE saturated with the same buffer both for batch and flow systems.

\subsection{Batch Reactions}

The initial experiments were directed towards rigorously establishing a system that enabled recycling experiments. The immobilisation of GtHNL-3V on Celite R-633 was therefore evaluated by a leaching test under reaction conditions. The immobilised enzyme was removed from the reaction mixture after $2 \mathrm{~h}$ and samples were taken shortly after removing the enzyme and after $4 \mathrm{~h}$. If the enzyme does not leach from the carrier, no further conversion is expected. Indeed, this was the case. GtHNL-3V did not leach from Celite R-633 into the reaction medium (Figure S1). Different hydroxynitrile lyases (HNLs) such as Prunus amygdalus HNL (PaHNL) [35], Manihot esculenta HNL [34], Arabidopsis thaliana HNL (AtHNL) [33] and GtHNL [37] have been immobilised on Celite for the synthesis of cyanohydrins using buffer saturated organic solvents as reaction medium. In all cases, the enzyme did not leach from Celite. The insolubility of the enzyme in organic solvents explains these results. 
Having established that GtHNL-3V does not leach from Celite R-633 under reaction conditions, time studies with different enzyme loadings of immobilised GtHNL-3V were performed (Figure 1). A total of 75\% formation of (R)-NPE and excellent enantioselectivity (>99\%) were achieved with $22 \mathrm{U}$ of GtHNL-3V (5.74 mg) on $50 \mathrm{mg}$ Celite R-633 after $4 \mathrm{~h}$. Commonly a low $\mathrm{pH}$ is used for the HNL catalysed synthesis of cyanohydrins to avoid the chemical racemic background reaction. This non-selective product formation is not relevant for the nitroaldol reaction, most probably due to the reduced solubility of nitromethane in the aqueous phase $[9,15]$. Therefore, $100 \mathrm{mM}$ potassium phosphate buffer $\mathrm{pH} 7$ was used for the saturation of MTBE. This enables higher GtHNL-3V activity as it is in the ideal $\mathrm{pH}$ range of the enzyme. Neither Celite R-633 nor $0.25 \mathrm{mM} \mathrm{MnCl}_{2}$ (negative controls) catalysed the non-selective nitroaldol reaction in the absence of GtHNL-3V (data not shown). An earlier report [12] showed 30\% formation of (R)-NPE and enantioselectivity of $95.8 \%$ after equal reaction time using $0.5 \mathrm{mg}$ of $\mathrm{G} t \mathrm{HNL}-3 \mathrm{~V}$, however, in a biphasic system. The Hevea brasiliensis HNL $(\mathrm{HbHNL})$ catalysed synthesis of several chiral $\beta$-nitro alcohols in a biphasic system [9] provided $63 \%$ of $(S)$-NPE with $92 \%$ ee. In kinetic resolutions, another approach commonly used to synthesise chiral $\beta$-nitro alcohols with HNLs, the (S)-selective HNL from Hevea brasiliensis (HbHNL) catalysed the decomposition of (S)-NPE yielding (R)-NPE [13]. The resolution was conducted to almost completion (49\%) with excellent enantioselectivity $(95 \%)$. Product inhibition due to the aldehyde formed during the reaction was overcome by adding hydrogen cyanide to the reaction mixture, this enabled the formation of the less inhibitive mandelonitrile. Likewise, the AtHNL catalysed kinetic resolution of racemic NPE has been reported [15]. AtHNL (27 U) immobilised on Celite R-545 was used in a biphasic system which resulted in $47 \%$ of conversion and $97 \%$ of enantiomeric excess after six hours of reaction time. Overall, the good yield and excellent enantioselectivity achieved by GtHNL-3V on Celite using buffer saturated MTBE as a reaction medium surpass the reduced $e e$, mass transfer, and work-up limitations of the biphasic approach as well as the limited yield (50\%) of kinetic resolutions.

In the cyanohydrin synthesis reactions, the Celite immobilised HNLs all had to be dried before their application in buffer saturated solvents. Here the opposite was observed. GtHNL-3V on Celite R-633 was not dried after immobilisation. When dried after immobilisation, the synthesis of $(R)$-NPE dropped to $41.12 \pm 0.62 \%$ even after prolonged reaction times $(24 \mathrm{~h})$. The water content and more accurately the water activity $\left(\mathrm{a}_{\mathrm{w}}\right)$ of CeliteGtHNL-3V is a crucial parameter in biocatalysis since enzymes, excluding lipases [38], need some water for conformational flexibility. Earlier studies [33] have shown the influence of the water content on the activity of immobilised AtHNL on Celite R-633, where $10 \%(w / w)$ water content inside $A t \mathrm{HNL}-\mathrm{Celite}$ was needed for optimal enzymatic activity. Similarly, the stability of $M e H N L$ as CLEA or immobilised on Celite R-633 is highly dependent on the water content entrapped in the carrier [34]. In general, the use of buffer saturated organic solvent provides the water that enzymes need for flexibility and to facilitate reproducibility. However, in this reaction a high concentration of nitromethane was used. This compound has a $\operatorname{low} \log P$ of -0.24 [39] and influences the overall polarity of the reaction mixture. While buffer saturated MTBE would normally represent an $\mathrm{a}_{\mathrm{w}}$ of 1 , this is no longer the case at high nitromethane concentrations. Thus, the water entrapped in Celite-GtHNL-3V can diffuse into the reaction mixture, as a result, the enzyme was deactivated rapidly. Earlier, the effect of $\mathrm{a}_{\mathrm{w}}$ on enzymes in organic media was reported [40]. The activity and enantioselectivity of $\mathrm{MeHNL}-\mathrm{CLEA}$ in organic solvents with different polarity at different $\mathrm{a}_{\mathrm{w}}$ has been investigated previously. The release of water from $\mathrm{MeHNL}-\mathrm{CLEA}$ (and subsequent deactivation) depended on changes in the polarity of the solvent due to the addition of reagents. The negative effect of dehydration on the catalytic activity of enzymes has been extensively studied [41-43]. 


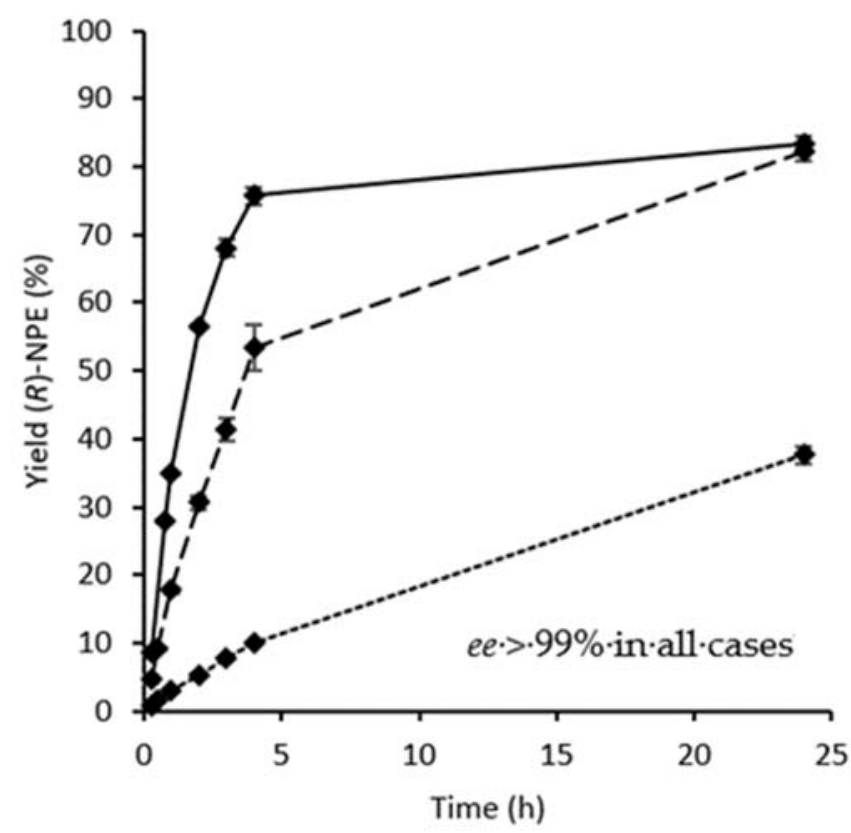

Figure 1. Synthesis of (R)-2-nitro-1-phenylethanol using different enzyme loadings on $50 \mathrm{mg}$ of Celite R-633. Solid line (22 U, final $e e>99 \%$ ), dashed line (10 U, final $e e>99 \%$ ) and dotted line (1 U, final ee > 99\%). Conditions: Ratio benzaldehyde:nitromethane, 1:50, $20 \mathrm{mM}$ benzaldehyde in MTBE saturated with $100 \mathrm{mM} \mathrm{KPi}$ buffer pH 7, 1 M nitromethane, $20 \mathrm{mM}$ 1,3,5-tri-isopropylbenzene in MTBE saturated with $100 \mathrm{mM} \mathrm{KPi}$ buffer $\mathrm{pH} 7$ as internal standard (I.S) and GtHNL-3V immobilised on $50 \mathrm{mg}$ Celite R-633. The immobilised GtHNL-3V was freely placed into the glass reaction vial. Reaction volume $1 \mathrm{~mL}$. The reaction was shaken at $1200 \mathrm{rpm}$ at $30^{\circ} \mathrm{C}$. Error bars correspond to the standard deviation of duplicates $(n=2)$. The yield of $(R)$-NPE was calculated by the ratio of $(R)-\mathrm{NPE}$ concentration to the initial benzaldehyde concentration.

Omitting the drying step after the enzyme immobilisation enabled high catalytic activity and excellent enantioselectivity. The stability of GtHNL-3V on Celite R-633 for the synthesis of $(R)$-NPE in the batch system was evaluated by a recycling study (Figure 2). An enzyme loading of $10 \mathrm{U} / 50 \mathrm{mg}$ Celite was used to observe any loss of activity due to enzyme deactivation. Higher activity and stability were observed when Celite-GtHNL-3V was rehydrated with $50 \mu \mathrm{L}$ of $100 \mathrm{mM}$ potassium phosphate buffer $\mathrm{pH} 7$ after each cycle (Figure 2, blue bars). The increasing yield during the first three cycles might be related to the addition of a buffer after each cycle and suggests that the $a_{w}$ was not optimal for the enzymatic activity during the first two cycles. After five cycles a significant decrease in activity was observed. In contrast, the experiments without buffer addition between cycles displayed lower yields and lower recyclability (Figure 2, dashed bars). Remarkably, an excellent enantiomeric excess was achieved under all conditions evaluated. The recyclability of GtHNL-3V immobilised on Celite R-633 for the synthesis of $(R)$-mandelonitrile has been reported for the cyanohydrin synthesis [37]. A high stability of the enzyme was observed. The biocatalyst was recycled eight times with excellent enantioselectivity whereas yields gradually dropped to $>70 \%$ over all cycles. Recently, the stability of $A t \mathrm{HNL}$ on Celite R-545 for the kinetic resolution of racemic NPE was reported [15]. The immobilised enzyme was stable during four cycles but a decrease in enantioselectivity (from $97 \%$ to $40 \%$ ) was reported. According to the authors, enzyme leaching might be a possible explanation since the reaction was performed in a biphasic system and the immobilisation of AtHNL on Celite R-545 involves weak interactions such as hydrogen bonding and van der Waals forces. The use of a buffer saturated organic solvent as a reaction medium is a straightforward approach to circumvent this limitation. 


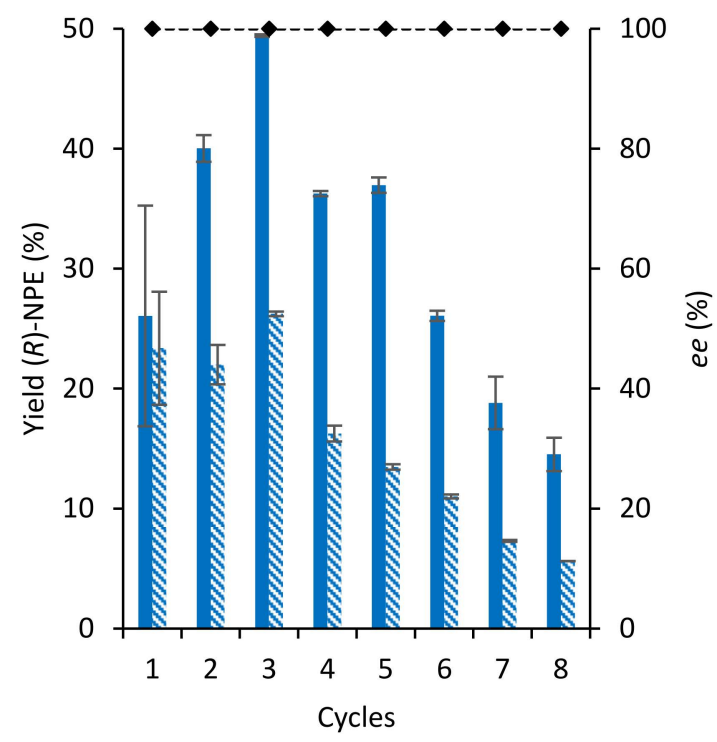

Figure 2. Recycling of GtHNL-3V on Celite R-633 (10 U/50 mg) for the synthesis of (R)-2-nitro-1phenylethanol in eight successive cycles. Blue bars (yields with the addition of $50 \mu \mathrm{L}$ of $100 \mathrm{mM}$ potassium phosphate buffer $\mathrm{pH} 7$ starting after the first cycle), dashed bars (yields without addition of $100 \mathrm{mM}$ potassium phosphate buffer $\mathrm{pH} 7$ between cycles), enantiomeric excess (dotted line and diamonds). Conditions: Ratio benzaldehyde:nitromethane, 1:50, $20 \mathrm{mM}$ benzaldehyde in MTBE saturated with $100 \mathrm{mM} \mathrm{KPi}$ buffer pH 7, 1 M nitromethane, $20 \mathrm{mM}$ 1,3,5-tri-isopropylbenzene in MTBE saturated with $100 \mathrm{mM} \mathrm{KPi} \mathrm{buffer} \mathrm{pH} 7$ as internal standard (I.S) and GtHNL-3V immobilised on $50 \mathrm{mg}$ Celite R-633. The immobilised GtHNL-3V was freely placed into the glass reaction vial. Reaction volume $1 \mathrm{~mL}$. The reaction was shaken at $1200 \mathrm{rpm}$ at $30^{\circ} \mathrm{C}$. Error bars correspond to the standard deviation of duplicates $(n=2)$. The enzyme was washed for 1 min (twice) with MTBE saturated with $100 \mathrm{mM} \mathrm{KPi}$ buffer $\mathrm{pH} 7$ after each cycle. Reaction time: $2 \mathrm{~h}$. Error bars correspond to the standard deviation of duplicates $(n=2)$. The yield of $(R)$-NPE was calculated by the ratio of $(R)-\mathrm{NPE}$ concentration to the initial benzaldehyde concentration.

\subsection{Continuous Flow Reactions}

The immobilisation of GtHNL-3V allows the continuous synthesis of (R)-NPE leading potentially to process intensification. The enzyme was tested in flow either re-hydrated or not dried after immobilisation with a flow rate of $0.1 \mathrm{~mL} \mathrm{~min}^{-1}$ or $0.01 \mathrm{~mL} \mathrm{~min}{ }^{-1}$, respectively (Figure 3). Figure 3A shows that the enzyme is not stable at $0.1 \mathrm{~mL} \mathrm{~min}{ }^{-1}$ and a steady decrease in yield was observed over time during $4 \mathrm{~h}$ on a stream. The use of a lower flow rate $\left(0.01 \mathrm{~mL} \mathrm{~min}^{-1}\right)$ (Figure $3 \mathrm{~B}$ ) allowed the continuous synthesis of $(R)-\mathrm{NPE}$ over a period of $15 \mathrm{~h}$. The potentially enhanced stability at a lower flow rate might be explained by the improved ability of Celite to keep the water entrapped whereas higher flow rate removes the water inside Celite-GtHNL-3V more rapidly. This suggests that a higher yield might be possible at longer residence times. Indeed, when GtHNL-3V on Celite R-633 and substrates were allowed to react during $2 \mathrm{~h}$ or even $20 \mathrm{~h}$ in the flow reactor the yield increased to $47.5 \%$ and $80.3 \%$, respectively (Table 1 ). This pulsed flow approach can solve the problem of water removal. 
A

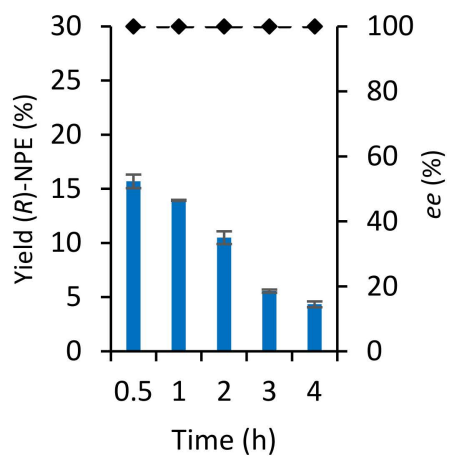

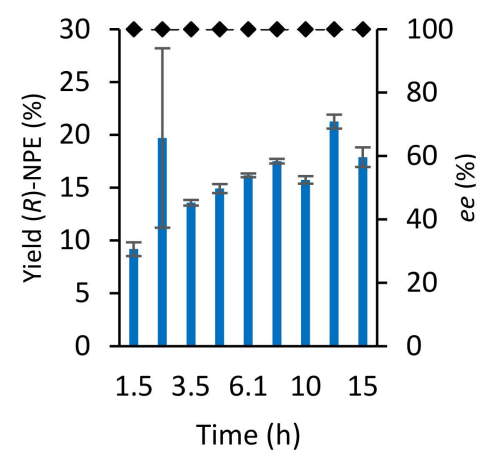

C

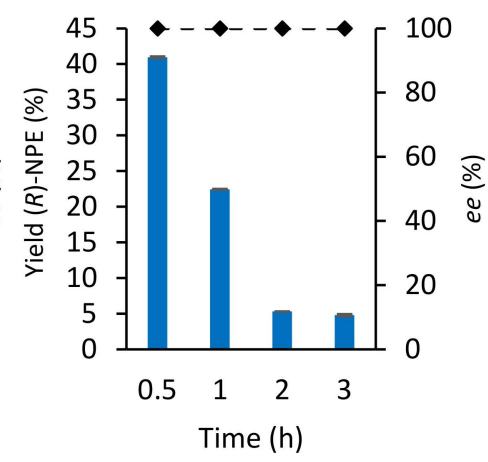

Figure 3. Stability of GtHNL-3V on Celite R-633 for the continuous synthesis of (R)-2-nitro-1phenylethanol in a packed bed reactor. (A) Conditions: Ratio benzaldehyde:nitromethane, 1:50, $20 \mathrm{mM}$ benzaldehyde, $1 \mathrm{M}$ nitromethane, $20 \mathrm{mM}$ 1,3,5-tri-isopropylbenzene as internal standard (I.S) in MTBE saturated with $100 \mathrm{mM} \mathrm{KPi}$ buffer pH 7 with GtHNL-3V (400 U) immobilised on

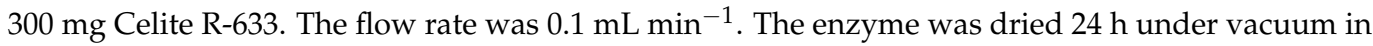
a desiccator over silica gel and re-hydrated with $1 \mathrm{~mL} 100 \mathrm{mM}$ potassium phosphate buffer $\mathrm{pH} 7$ prior to the reaction. (B) Conditions: Ratio benzaldehyde:nitromethane, 1:50, $20 \mathrm{mM}$ benzaldehyde, $1 \mathrm{M}$ nitromethane, $20 \mathrm{mM}$ 1,3,5-tri-isopropylbenzene as internal standard (I.S) in MTBE saturated with $100 \mathrm{mM}$ KPi buffer pH 7 with GtHNL-3V (450 U) immobilised on $500 \mathrm{mg}$ Celite R-633. The flow rate was $0.01 \mathrm{~mL} \mathrm{~min}^{-1}$. The enzyme was not dried after its immobilisation. (C): Conditions: Ratio benzaldehyde:nitromethane, 1:50, 40 mM benzaldehyde, 2 M nitromethane, 40 mM 1,3,5-triisopropylbenzene as internal standard (I.S) in MTBE saturated with $100 \mathrm{mM} \mathrm{KPi}$ buffer pH 7, $100 \mathrm{mM}$ KPi buffer pH 7 with GtHNL-3V (450 U) immobilised on $500 \mathrm{mg}$ Celite R-633. The reaction was performed in a biphasic $50 / 50 \%$ system. The flow rate was $0.1 \mathrm{~mL} \mathrm{~min}^{-1}$. The enzyme was not dried after its immobilisation. Yield (bars) and enantiomeric excess (dashed lines). Error bars correspond to the standard deviation of duplicates $(n=2)$. The yield of $(R)$-NPE was calculated by the ratio of $(R)$-NPE concentration to the initial benzaldehyde concentration.

Table 1. Influence of residence time on the continuous synthesis of (R)-NPE catalysed by GtHNL-3V on Celite R-633 in potassium phosphate buffer (100 mM, pH 7) saturated MTBE as reaction medium.

\begin{tabular}{|c|c|c|c|c|}
\hline Flow Rate $\left(\mathrm{mL} \min ^{-1}\right)$ & Residence Time $^{a}$ (min) & Enzyme Loading (U) & Yield (R)-NPE ${ }^{\mathrm{b}}(\%)$ & $e e(\%)$ \\
\hline 0.1 & 7.3 & 400 & $15.7^{\mathrm{c}}$ & $>99$ \\
\hline 0.01 & 43.8 & 450 & $16.2^{\mathrm{d}}$ & $>99$ \\
\hline 0.01 & $120^{\mathrm{e}}$ & 450 & 47.5 & $>99$ \\
\hline 0.01 & $1200^{\mathrm{e}}$ & 450 & 80.3 & $>99$ \\
\hline
\end{tabular}

${ }^{\mathrm{a}}$ Calculated as the ratio of reaction volume to flow rate. The reaction volume was calculated based on the pore volume of Celite R-633 (1.46 mL g ${ }^{-1}$ [44]) and the amount (g) of carrier used. ${ }^{\mathrm{b}}$ Calculated by the ratio of (R)-NPE concentration to the initial benzaldehyde concentration. ${ }^{\mathrm{C}}$ Calculated after $30 \mathrm{~min}$ reaction time. ${ }^{\mathrm{d}}$ Average of $15 \mathrm{~h}$ of reaction time. ${ }^{\mathrm{e}}$ The pump was turned off to allow the desired retention time.

Likewise, the development of a biphasic system is another approach to maintain Celite-GtHNL-3V hydration over time. Figure 3C shows a higher yield of (R)-NPE (44\%) during the first $30 \mathrm{~min}$ of reaction time. Unfortunately, the biphasic system $(50 / 50 \%)$ was not stable and a significant decrease in yield was observed after $1 \mathrm{~h}$. This can be explained by the leaching of the enzyme to the reaction medium due to the weak interactions between Celite-GtHNL-3V and the solubility of the enzyme in the reaction medium as observed earlier for a similar system [15]. The immobilization of GtHNL-3V by covalent attachment might be a viable alternative to overcome the leaching limitation observed in this biphasic system. Remarkably, the enantiomeric excess is excellent in all conditions evaluated. 


\subsection{Comparison between Batch and Continuous Flow Systems}

A fair comparison between batch and continuous flow systems can be made based on their space-time-yields (STYs). The product formation over time is not a linear function in batch and flow systems; thus, the comparison must be made at the same level of conversion [25]. Table 2 shows the STYs of the batch and continuous flow systems using MTBE saturated with $100 \mathrm{mM} \mathrm{KPi} \mathrm{buffer} \mathrm{pH} 7$ as reaction medium. The batch and flow systems displayed similar productivity at $0.01 \mathrm{~mL} \mathrm{~min}^{-1}$. The use of a higher flow rate $\left(0.1 \mathrm{~mL} \mathrm{~min}{ }^{-1}\right)$ improved the STY $\left(\mathrm{g} \mathrm{L}^{-1} \mathrm{~h}^{-1}\right)$ seven times. However, the enzyme was not stable at this flow rate (Figure $3 \mathrm{~A}$ ). When the amount of enzyme used for the reactions is taken into account, the productivity of the batch system is 5 and 37 times higher compared with both flow rates $\left(0.1 \mathrm{~mL} \mathrm{~min}^{-1}\right.$ and $\left.0.01 \mathrm{~mL} \mathrm{~min}^{-1}\right)$ respectively. The reaction conditions for the Celite-GtHNL-3V catalysed synthesis of $(R)$-NPE evaluated in this study were more stable and controlled in the batch system. This explains its higher productivity. This result is unexpected since flow systems commonly allowed process intensification $[25,26,37,45,46]$. However, the high concentration $(1 \mathrm{M})$ and low polarity $(\log P=-0.27)$ of nitromethane might not maintain a constant $\mathrm{a}_{\mathrm{w}}$ on Celite-GtHNL-3V. While significant fluctuations in enzyme activity and therefore yield were observed, remarkably the enantioselectivity of the reaction was unaffected and always excellent.

Table 2. Comparison of batch and flow systems based on their productivity.

\begin{tabular}{ccc}
\hline & Batch & Flow \\
\hline $\mathrm{STY}^{\mathrm{a}}\left(\mathrm{g} \mathrm{L}^{-1} \mathrm{~h}^{-1}\right)$ & 0.60 & $4.31^{\mathrm{b}}$ \\
& & $0.69^{\mathrm{c}}$ \\
\hline $\mathrm{STY}^{\mathrm{a}}\left(\mathrm{g} \mathrm{L}^{-1} \mathrm{~h}^{-1} \mathrm{mg}_{\text {enzyme }}{ }^{-1}\right)$ & 0.10 & $0.02^{\mathrm{b}}$ \\
& & $0.003^{\mathrm{c}}$ \\
\hline
\end{tabular}

${ }^{a}$ Calculated at similar yield levels $(\text { circa } 16 \%)^{\mathrm{b}}$ Calculated at $0.1 \mathrm{~mL} \mathrm{~min}^{-1}$. ${ }^{\mathrm{c}}$ Calculated at $0.01 \mathrm{~mL} \mathrm{~min}{ }^{-1}$.

\section{Materials and Methods}

\subsection{Chemicals}

Except when reported otherwise, all chemicals were obtained from Sigma Aldrich (Schnelldorf, Germany). Isopropanol and heptane were of HPLC graded ( $\geq 99 \%$ ) and used as HPLC solvents. The 1,3,5-triisopropylbenzene (97\%) was from Fluka Chemie (Buchs, Switzerland). ( \pm )-Mandelonitrile from Across Organics (Geel, Belgium) was purified by flash chromatography (PE/MTBE 9:1/3:7). The ( \pm )-2-nitro-1-phenylethanol was prepared according to the literature [47].

\subsection{Cloning and Heterologous Expression of Granulicella tundricola HNL (GtHNL)}

The pUC57 shuttle vector containing the gene encoding GtHNL-A40H/V42T/Q110H, codon optimised for E. coli was obtained from Bio Basic INC (Markham, Canada) and used to transform E. coli Top 10. The gene encoding GtHNL-A40H/V42T/Q110H gene was cloned into the pET28a expression vector using NcoI and HindIII restriction enzymes. The resulting pET28a-GtHNL-A40H/V42T/Q110H expression vector was cloned into E. coli TOP 10 to obtain a stable host for plasmid DNA and sequenced to ensure the successful introduction of the H96A mutation (Table S1). Finally, pET28a-GtHNLA-40H/V42T/Q110H was used to transform the expression host E. coli BL21(DE3). The enzyme cultivation was performed in accordance with the literature [37]. A preculture was prepared by inoculating one single colony of E. coli BL21(DE3)-pET28aGtHNL in $10 \mathrm{~mL}$ of LB medium with kanamycin $(40 \mu \mathrm{g} / \mathrm{mL})$ and incubated overnight (New Brunswick Scientific Incubator Shaker Excella E24 Series, Nijmegen, The Netherlands) at $37^{\circ} \mathrm{C}, 180 \mathrm{rpm}$. Then, this preculture was used for the inoculation of $1 \mathrm{~L}$ of LB medium containing kanamycin $(40 \mu \mathrm{g} / \mathrm{mL})$ and incubated at $37^{\circ} \mathrm{C}, 120 \mathrm{rpm}$. When the OD600 reached 0.7-0.9 the gene expression was induced by adding $1 \mathrm{~mL}$ of $0.1 \mathrm{M}$ isopropyl $\beta$-D-thioacetamide (IPTG) per litre of culture (0.1 mM IPTG final concentration) and cultivation was continued overnight at $25^{\circ} \mathrm{C}$, 
$120 \mathrm{rpm}$. Moreover, $100 \mu \mathrm{L}$ of $1 \mathrm{M} \mathrm{MnCl}_{2}$ was added per litre of culture at the induction time $\left(0.1 \mathrm{mM} \mathrm{Mn}^{2+}\right.$ final concentration). Cells were harvested at $4{ }^{\circ} \mathrm{C}, 5000 \mathrm{rpm}$ during 20 min (Sorvall RC6, Thermo Scientific, Landsmeer, The Netherlands). The supernatant was discarded, and the pellet was washed with $20 \mathrm{~mL}$ of $10 \mathrm{mM}$ sodium phosphate buffer, $\mathrm{pH} 7$, and stored at $-80{ }^{\circ} \mathrm{C}$.

\subsection{Enzyme Purification}

The pellets of GtHNL-3V were resuspended in lysis buffer (50 mM potassium phosphate buffer + DNAse) pH 7 and lysed in a cell disruptor (Constant Systems Ltd., Daventry, $\mathrm{UK}$ ) at $20 \mathrm{kPSI}$ and $4{ }^{\circ} \mathrm{C}$ to avoid protein denaturation. The cell free extract (CFE) was collected as the supernatant after centrifugation at $4500 \mathrm{~g}, 1 \mathrm{~h}, 4^{\circ} \mathrm{C}$, heated during $30 \mathrm{~min}$ at $65{ }^{\circ} \mathrm{C}$, and centrifuged during $15 \mathrm{~min}$ at $4500 \mathrm{~g}$. The purified enzyme was found as the supernatant.

\subsection{Enzymatic Activity Assay}

GtHNL-3V activity was measured spectrophotometrically (Agilent Technologies Cary 60 UV-VIS, Amstelveen, The Netherlands) using a method previously reported [48]. The cleavage of $r a c$-mandelonitrile into benzaldehyde and hydrogen cyanide was followed at $280 \mathrm{~nm}$ and $25^{\circ} \mathrm{C}$ in quartz glass cuvettes. To $1300 \mu \mathrm{L}$ of reaction buffer $(100 \mathrm{mM}$ sodium oxalate buffer, $\mathrm{pH}$ 5), $200 \mu \mathrm{L}$ of enzyme solution (diluted in reaction buffer) and $500 \mu \mathrm{L}$ of $60 \mathrm{mM}$ rac-mandelonitrile solution (dissolved in $3 \mathrm{mM}$ oxalic acid, $\mathrm{pH} 3$ ) were added. The background reaction was evaluated without enzyme and its slope was subtracted in the final calculation. The activity was calculated based on the following equation:

$$
\text { Activity }=(2.0 \times \Delta \mathrm{A} / \mathrm{min}) /(\varepsilon 280 \times 1 \times 0.2)[\mathrm{U} / \mathrm{mL} \text { diluted sample }]
$$

where

$$
\begin{gathered}
\Delta \mathrm{A} / \min =\Delta \mathrm{A} / \min _{\text {sample }}-\Delta \mathrm{A} / \min _{\text {blank }} \\
\varepsilon_{280}=1.376\left[\mathrm{mM}^{-1} \times \mathrm{cm}^{-1}\right]
\end{gathered}
$$

One unit of HNL activity is defined as one micromole of rac-mandelonitrile converted per minute in $100 \mathrm{mM}$ sodium oxalate buffer $\mathrm{pH} 5$ at $25^{\circ} \mathrm{C}$.

\subsection{Immobilisation of GtHNL on Celite R-633 by Adsorption}

Enzyme immobilisation on Celite R-633 was performed according to the literature [34,37] with slight modifications. Celite R-633 has a pore diameter of $6.5 \mu \mathrm{m}$, a pore volume of $1.47 \mathrm{~mL} \mathrm{~g}^{-1}$ and a water absorption capability of $240 \%$ (Supplementary Information S2). It was washed with $100 \mathrm{mM}$ potassium phosphate buffer $\mathrm{pH} 7$ using a Büchner funnel and dried $24 \mathrm{~h}$ under vacuum in a desiccator over silica gel or used directly. Given volumes of GtHNL-3V were concentrated with Amicon ultrafiltration filters with a $10 \mathrm{kDa} \mathrm{MW}$ cut-off, and subsequently added dropwise to Celite R-633 and dried $24 \mathrm{~h}$ under vacuum in a desiccator over silica gel. The ratio of enzyme solution to carrier ( $\mu \mathrm{L}: \mathrm{mg}$ ) was 2:1. The enzyme concentration in the solutions was adjusted to the required amount of enzyme for the immobilisation. By using this ratio of enzyme solution to Celite, the enzyme solution was completely absorbed by the carrier, ensuring that all the enzyme was immobilised into the porous material. The immobilised enzyme was stored in the fridge at $4{ }^{\circ} \mathrm{C}$ when needed.

\subsection{Synthesis of (R)-2-Nitro-1-Phenylethanol in the Batch System}

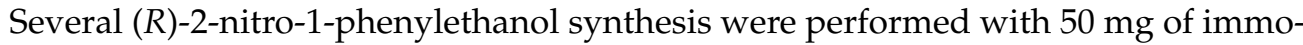
bilised GtHNL-3V on Celite R-633. The reaction conditions were as follows: $20 \mathrm{mM}$ benzaldehyde, $20 \mathrm{mM}$ 1,3,5-tri-isopropylbenzene (internal standard), $1 \mathrm{M}$ nitromethane and MTBE saturated with $100 \mathrm{mM} \mathrm{KPi}$ buffer $\mathrm{pH}$ 7, $50 \mathrm{mg}$ immobilised enzyme, $1200 \mathrm{rpm}$, and $30^{\circ} \mathrm{C}$. Shaking and temperature were controlled by using an Eppendorf thermomixer (Hamburg, Germany). The saturated MTBE was prepared by adding $5 \mathrm{~mL}$ of $100 \mathrm{mM}$ 
KPi buffer $\mathrm{pH} 7$ to $25 \mathrm{~mL}$ of dry MTBE. Reaction volume: $1 \mathrm{~mL}$. The ratio benzaldehyde to nitromethane was 1:50. The immobilised GtHNL-3V was freely placed into the glass reaction vial.

\subsection{Enzyme Recyclability in the Batch System}

The enzyme recyclability was determined through several cycles of $(R)-2$-nitro-1phenylethanol synthesis according to the literature $[34,37]$. Between each cycle the immobilised enzyme was washed twice for 1 min with MTBE saturated with $100 \mathrm{mM} \mathrm{KPi} \mathrm{buffer}$ $\mathrm{pH}$ 7. When required, $50 \mu \mathrm{L}$ of $100 \mathrm{mM} \mathrm{KPi}$ buffer were added to the immobilised enzyme. At the end of the working day the immobilised enzyme was stored at $4{ }^{\circ} \mathrm{C}$ in fresh MTBE saturated with $100 \mathrm{mM} \mathrm{KPi}$ buffer $\mathrm{pH}$ 7. The immobilised GtHNL-3V was freely placed into the glass reaction vial. The saturated MTBE was prepared by adding $5 \mathrm{~mL}$ of $100 \mathrm{mM}$ KPi buffer $\mathrm{pH} 7$ to $25 \mathrm{~mL}$ of dry MTBE.

\subsection{Enzyme Stability in Continuous Flow in a Monophasic KPi Saturated MTBE System}

A $1 \mathrm{~mL}$ stainless steel flow reactor was used for the continuous synthesis of $(R)$-2-nitro1-phenylethanol. Ten centimetre of polytetrafluoroethylene (PTFE) tubing with $1.5 \mathrm{~mm}$ inner diameter connected a syringe pump (Knauer, Berlin, Germany) with the reactor. The stability of $400 \mathrm{U}$ of immobilised GtHNL-3V on $300 \mathrm{mg}$ Celite R-633 was evaluated by performing a synthesis reaction during $4 \mathrm{~h}$ at $0.1 \mathrm{~mL} \mathrm{~min}^{-1}$ (reaction volume $=0.73 \mathrm{~mL}$ ). Likewise, the stability of $450 \mathrm{U}$ of immobilised GtHNL-3V on $500 \mathrm{mg}$ Celite R-633 was evaluated during $15 \mathrm{~h}$ at $0.01 \mathrm{~mL} \min ^{-1}$ (reaction volume $=0.44 \mathrm{~mL}$ ). The ratio was benzaldehyde:nitromethane, 1:50, $20 \mathrm{mM}$ benzaldehyde, $1 \mathrm{M}$ nitromethane, $20 \mathrm{mM} \mathrm{1,3,5-}$ tri-isopropylbenzene as internal standard (I.S) in MTBE saturated with $100 \mathrm{mM} \mathrm{KPi} \mathrm{buffer}$ $\mathrm{pH}$ 7. The reactions were performed at room temperature. The saturated MTBE was prepared by adding $5 \mathrm{~mL}$ of $100 \mathrm{mM}$ KPi buffer $\mathrm{pH} 7$ to $25 \mathrm{~mL}$ of dry MTBE. Samples were drawn at regular intervals and analysed by chiral HPLC. The flow rate was checked at each sampling time by the difference of weight.

\subsection{Enzyme Stability in Continuous Flow in a Biphasic System}

A similar setup as described in 3.8 was used. In this case, two syringes were connected to a mixing unit (T-piece assembly) to ensure a mixture of substrates and buffer. Syringe 1 was used for $40 \mathrm{mM}$ benzaldehyde, $2 \mathrm{M}$ nitromethane, and $40 \mathrm{mM}$ in 1,3,5-triisopropylbenzene in MTBE saturated with $100 \mathrm{mM} \mathrm{KPi} \mathrm{pH} \mathrm{7.} \mathrm{Syringe} 2$ was used for $100 \mathrm{mM}$ KPi pH 7. The stability of $450 \mathrm{U}$ of immobilised GtHNL-3V on $500 \mathrm{mg}$ Celite R-633 was evaluated by performing a synthesis reaction during $3 \mathrm{~h}$ at $0.1 \mathrm{~mL} \mathrm{~min}^{-1}$ (reaction volume $=0.73 \mathrm{~mL}$ ). The reaction was performed in a biphasic $50 / 50 \%$ system. The enzyme was not dried after its immobilisation. The reactions were performed at room temperature. Saturated MTBE was prepared by adding $5 \mathrm{~mL}$ of $100 \mathrm{mM} \mathrm{KPi}$ buffer $\mathrm{pH} 7$ to $25 \mathrm{~mL}$ of dry MTBE. Samples were drawn at regular intervals and analysed by chiral HPLC. The flow rate was checked at each sampling time by the difference of weight.

\subsection{Analysis}

Samples $(50 \mu \mathrm{L})$ were taken at different times during the reaction run and added to $450 \mu \mathrm{L}$ of heptane:2-propanol 90:10 in 1.5 mL Eppendorf tubes. A small amount of anhydrous magnesium sulphate $\left(\mathrm{MgSO}_{4}\right)$ was used to remove the water from the solution and the Eppendorf tubes were centrifuged at 13,000 rpm for $1 \mathrm{~min}$. The supernatant was transferred to a $1.5 \mathrm{~mL} \mathrm{HPLC}$ vial and $10 \mu \mathrm{L}$ was injected into the HPLC (Chiralcel OD column, column size: $0.46 \mathrm{~cm}$ I.D $\times 25 \mathrm{~cm}$ ) (Munich, Germany). Heptane and 2-propanol were used as mobile phase with a flow rate of $1 \mathrm{~mL} / \mathrm{min}$ and the UV detector was set at $210 \mathrm{~nm}$. The column temperature was set at $40^{\circ} \mathrm{C}$. The samples in the autosampler were maintained at $4{ }^{\circ} \mathrm{C}$. 
Supplementary Materials: The following are available online at https:/ /www.mdpi.com/article/10 .3390/catal12020161/s1, Figure S1: Leaching assay for GtHNL on Celite R-633 (10 U/50 mg Celite R-633), Table S1: GtHNL-A40H/V42T/Q110H gene sequence and the company information sheet on Celite as Supplementary Information S2.

Author Contributions: U.H. conceptualized and supervised the study; J.C., L.T. and M.A. performed the experiments; P.-L.H. reviewed the manuscript and supervised the study. J.C. wrote and edited the manuscript. All authors have read and agreed to the published version of the manuscript.

Funding: This research was funded by the Secretary of Higher Education, Science, Technology and Innovation of Ecuador (Senescyt) and Universidad Laica Eloy Alfaro de Manabí (ULEAM).

Data Availability Statement: The data presented in this study are available on request from the corresponding author.

Acknowledgments: The authors thank Eman Abdelraheem for the synthesis of ( \pm )-2-nitro-1-phenylethanol.

Conflicts of Interest: The authors declare no conflict of interest. The funders had no role in the design of the study; in the collection, analyses, or interpretation of data; in the writing of the manuscript, or in the decision to publish the results.

\section{References}

1. Rao, D.H.S.; Chatterjee, A.; Padhi, S.K. Biocatalytic approaches for enantio and diastereoselective synthesis of chiral $\beta$-nitroalcohols. Org. Biomol. Chem. 2021, 19, 322-337. [CrossRef] [PubMed]

2. Ono, N. The Nitro Group in Organic Synthesis; Wiley: New York, NY, USA, 2001.

3. Milner, S.E.; Moody, T.S.; Maguire, A.R. Biocatalytic approaches to the Henry (Nitroaldol) reaction. Eur. J. Org. Chem. 2012, 2012, 3059-3067. [CrossRef]

4. Lahssen, E.B.; Ahbala, M.; Bolte, J.; Lemaire, M. Straightforward chemo-enzymatic synthesis of new aminocyclitols, analogues of valiolamine and their evaluation as glycosidase inhibitors. Tetrahedron Asymmetry 2006, 17, 2684-2688.

5. Kühbeck, D.; Mayr, J.; Häring, M.; Hofmann, M.; Quignard, F.; Díaz, D.D. Evaluation of the nitroaldol reaction in the presence of metal ion-crosslinked alginates. New J. Chem. 2015, 39, 2306-2315. [CrossRef]

6. Vongvilai, P.; Angelin, M.; Larsson, R.; Ramström, O. Dynamic combinatorial resolution: Direct asymmetric lipase mediated screening of a dynamic nitroaldol library. Angew. Chem. Int. Ed. 2007, 46, 948-950. [CrossRef]

7. Vongvilai, P.; Larsson, R.; Ramström, O. Direct asymmetric dynamic kinetic resolution by combined lipase catalysis and nitroaldol (Henry) reaction. Adv. Synth. Catal. 2008, 350, 448-452. [CrossRef]

8. Zhang, Y.; Hu, L.; Ramström, O. Double parallel dynamic resolution through lipase-catalyzed asymmetric transformation. Chem. Commun. 2013, 49, 1805-1807. [CrossRef]

9. Purkarthofer, T.; Gruber, K.; Gruber-Khadjawi, M.; Waich, K.; Skranc, W.; Mink, D.; Griengl, H. A Biocatalytic Henry Reaction-The hydroxynitrile lyase from Hevea brasiliensis also catalyzes nitroaldol reactions. Angew. Chem. Int. Ed. 2006, 45, 3454-3456. [CrossRef]

10. Gruber-Khadjawi, M.; Purkarthofer, T.; Skranc, W.; Griengl, H. Hydroxynitrile lyase-catalyzed enzymatic nitroaldol (Henry) reaction. Adv. Synth. Catal. 2007, 349, 1445-1450. [CrossRef]

11. Fuhshuku, K.; Asano, Y. Synthesis of $(R)-\beta$-nitro alcohols catalyzed by $R$-selective hydroxynitrile lyase from Arabidopsis thaliana in the aqueous-organic biphasic system. J. Biotechnol. 2011, 153, 153-159. [CrossRef]

12. Bekerle-Bogner, M.; Gruber-Khadjawi, M.; Wiltsche, H.; Wiedner, R.; Schwab, H.; Steiner, K. (R)-selective nitroaldol reaction catalyzed by metal-dependent bacterial hydroxynitrile lyases. Chem CatChem 2016, 8, 2214-2216. [CrossRef]

13. Yuryev, R.; Briechle, S.; Gruber-Khadjawi, M.; Griengl, H.; Liese, A. Asymmetric retro-Henry reaction catalyzed by hydroxynitrile lyase from Hevea brasiliensis. ChemCatChem 2010, 2, 981-986. [CrossRef]

14. Rao, D.H.S.; Padhi, S.K. Production of (S)- $\beta$-Nitro alcohols by enantioselective C-C bond cleavage with an $R$-selective hydroxynitrile lyase. ChemBioChem 2019, 20, 371-378. [CrossRef]

15. Rao, D.H.S.; Shivani, K.; Padhi, S.K. Immobilized Arabidopsis thaliana hydroxynitrile lyase-catalyzed retro-henry reaction in the synthesis of (S)- $\beta$-Nitroalcohols. Appl. Biochem. Biotechnol. 2021, 193, 560-576. [CrossRef] [PubMed]

16. Von Langermann, J.; Nedrud, D.M.; Kazlauskas, R.J. Increasing the reaction rate of hydroxynitrile lyase from Hevea brasiliensis towards mandelonitrile by copying active site residues from an esterase that accepts aromatic esters. ChemBioChem 2014, 15, 1931-1938. [CrossRef] [PubMed]

17. Devamani, T.; Rauwerdink, A.M.; Lunzer, M.; Jones, B.J.; Mooney, J.L.; Tan, M.A.O.; Zhang, Z.J.; Xu, J.H.; Dean, A.M.; Kazlauskas, R.J. Catalytic promiscuity of ancestral esterases and hydroxynitrile lyases. J. Am. Chem. Soc. 2016, 138, 1046-1056. [CrossRef] [PubMed]

18. Tentori, F.; Brenna, E.; Colombo, D.; Crotti, M.; Gatti, F.G.; Ghezzi, M.C.; Pedrocchi-Fantoni, G. Biocatalytic approach to chiral $\beta$-nitroalcohols by enantioselective alcohol dehydrogenase-mediated reduction of $\alpha$-nitroketones. Catalysts 2018, 8, 308. [CrossRef] 
19. Wang, Z.; Wu, X.; Li, Z.; Huang, Z.; Chen, F. Ketoreductase catalyzed stereoselective bioreduction of $\alpha$-nitro ketones. Org. Biomol. Chem. 2019, 17, 3575-3580. [CrossRef]

20. Venkataraman, S.; Chadha, A. Enantio- $\delta$ chemo-selective preparation of enantiomerically enriched aliphatic nitro alcohols using Candida parapsilosis ATCC 7330. RSC Adv. 2015, 5, 73807-73813. [CrossRef]

21. Chadha, A.; Venkataraman, S.; Preetha, R.; Padhi, S.K. Candida parapsilosis: A versatile biocatalyst for organic oxidation-reduction reactions. Bioorg. Chem. 2016, 68, 187-213. [CrossRef]

22. Wallner, S.R.; Lavandera, I.; Mayer, S.F.; Öhrlein, R.; Hafner, A.; Edegger, K.; Faber, K.; Kroutil, W. Stereoselective anti-Prelog reduction of ketones by whole cells of Comamonas testosteroni in a 'substrate-coupled' approach. J. Mol. Catal. B Enzym. 2008, 55, 126-129. [CrossRef]

23. Hasnaoui, G.; Lutje Spelberg, J.H.; De Vries, E.; Tang, L.; Hauer, B.; Janssen, D.B. Nitrite-mediated hydrolysis of epoxides catalyzed by halohydrin dehalogenase from Agrobacterium radiobacter AD1: A new tool for the kinetic resolution of epoxides. Tetrahedron: Asymmetry 2005, 16, 1685-1692. [CrossRef]

24. Hasnaoui-Dijoux, G.; Elenkov, M.M.; Lutje Spelberg, J.H.; Hauer, B.; Janssen, D.B. Catalytic promiscuity of halohydrin dehalogenase and its application in enantioselective epoxide ring opening. ChemBioChem 2008, 9, 1048-1051. [CrossRef] [PubMed]

25. Coloma, J.; Guiavarc'h, Y.; Hagedoorn, P.L.; Hanefeld, U. Immobilisation and flow chemistry: Tools for implementing biocatalysis. Chem. Commun. 2021, 57, 11416. [CrossRef] [PubMed]

26. Brahma, A.; Musio, B.; Ismayilova, U.; Nikbin, N.; Kamptmann, S.; Siegert, P.; Jeromin, G.E.; Ley, S.V.; Pohl, M. An orthogonal biocatalytic approach for the safe generation and use of HCN in a multistep continuous preparation of chiral O-Acetylcyanohydrins. Synlett 2016, 27, 262-266. [CrossRef]

27. Bouchaut, B.; Asveld, L.; Hanefeld, U.; Vlierboom, A. Value Conflicts in Designing for Safety: Distinguishing Applications of Safe-by-Design and the Inherent Safety Principles. Int. J. Environ. Res. Public Health 2021, 18, 1963. [CrossRef]

28. Naramittanakul, S.; Buttranon, A.; Petchsuk, P.; Chaiyen, N.; Weeranoppanant, N. Development of a continuous-flow system with immobilised biocatalysts towards sustainable bioprocessing. React. Chem. Eng. 2021, 6, 1771-1790. [CrossRef]

29. Benitez-Mateos, I.; Contente, M.L.; Roura Padrosa, D.; Paradisi, F. Flow biocatalysis 101: Design, development and applications. React. Chem. Eng. 2021, 6, 599. [CrossRef]

30. Boodhoo, K.V.K.; Flickinger, M.C.; Woodley, J.M.; Emanuelsson, E.A.C. Bioprocess intensification: A route to efficient and sustainable biocatalytic transformations for the future. Chem. Eng. Process. -Process. Intensif. 2022, 172, 108793. [CrossRef]

31. De Santis, P.; Meyer, L.-E.; Kara, S. The rise of continuous flow biocatalysis - fundamentals, very recent developments and future perspectives. React. Chem. Eng. 2020, 5, 2155-2184. [CrossRef]

32. Cosgrove, C.; Mattey, A.P. Reaching new biocatalytic reactivity using continuous flow reactors. Chem. Eur. J. 2022, e202103607. [CrossRef]

33. Okrob, D.; Paravidino, M.; Orru, R.V.A.; Wiechert, W.; Hanefeld, U.; Pohl, M. Hydroxynitrile lyase from Arabidopsis thaliana: Identification of reaction parameters for enantiopure cyanohydrin synthesis by pure and immobilized catalyst. Adv. Synth. Catal. 2011, 353, 2399-2408. [CrossRef]

34. Torrelo, G.; van Midden, N.; Stloukal, R.; Hanefeld, U. Immobilized hydroxynitrile lyase: A comparative study of recyclability. ChemCatChem 2014, 6, 1096-1102. [CrossRef]

35. Bracco, P.; Torrelo, G.; Noordam, S.; de Jong, G.; Hanefeld, U. Immobilization of Prunus amygdalus hydroxynitrile lyase on Celite. Catalysts 2018, 8, 287. [CrossRef]

36. Hanefeld, U.; Gardossi, L.; Magner, E. Understanding enzyme immobilisation. Chem. Soc. Rev. 2009, 38, 453-468. [CrossRef] [PubMed]

37. Coloma, J.; Guiavarc'h, Y.; Hagedoorn, P.L.; Hanefeld, U. Probing batch and continuous flow reactions in organic solvents: Granulicella tundricola hydroxynitrile lyase (GtHNL). Catal. Sci. Technol. 2020, 10, 3613-3621. [CrossRef]

38. Bracco, P.; van Midden, N.; Arango, E.; Torrelo, G.; Ferrario, V.; Gardossi, L.; Hanefeld, U. Bacillus subtilis Lipase A-Lipase or esterase? Catalysts 2020, 10, 308. [CrossRef]

39. Valivety, R.H.; Johnston, G.A.; Suckling, C.J.; Halling, P.J. Solvent effects on biocatalysis in organic systems: Equilibrium position and rates of lipase catalyzed esterification. Biotechnol. Bioeng. 1991, 38, 1137-1143. [CrossRef]

40. Paravidino, M.; Sorgedrager, M.J.; Orru, R.V.; Hanefeld, U. Activity and enantioselectivity of the hydroxynitrile lyase MeHNL in dry organic solvents. Chemistry 2010, 16, 7596-7604. [CrossRef]

41. Klibanov, A.M. Why are enzymes less active in organic solvents than in water? Trends Biotechnol. 1997, 15, 97-101. [CrossRef]

42. Griebenow, K.; Klibanov, A.M. Lyophilization-induced reversible changes in the secondary structure of proteins. Proc. Natl. Acad. Sci. USA 1995, 92, 10969-10976. [CrossRef] [PubMed]

43. Griebenow, K.; Klibanov, A.M. Can Conformational Changes Be Responsible for Solvent and Excipient Effects on the Catalytic Behavior of Subtilisin Carlsberg in Organic Solvents? Biotechnol. Bioeng. 1997, 53, 351-362. [CrossRef]

44. El-Sayed, A.H.M.M.; Mahmoud, W.M.; Coughlin, R.W. Comparative study of production of dextransucrase and dextran by cells of Leuconostoc mesenteroides immobilized on Celite and in calcium alginate beads. Biotechnol. Bioeng. 1990, 36, 83-91. [CrossRef] [PubMed]

45. Coloma, J.; Lugtenburg, T.; Afendi, M.; Lazzarotto, M.; Bracco, P.; Hagedoorn, P.L.; Gardossi, L.; Hanefeld, U. Immobilization of Arabidopsis thaliana hydroxynitrile lyase (AtHNL) on EziG Opal. Catalysts 2020, 10, 899. [CrossRef] 
46. Van der Helm, M.P.; Bracco, P.; Busch, H.; Szymańska, K.; Jarzębski, A.; Hanefeld, U. Hydroxynitrile lyases covalently immobilized in continuous flow microreactors. Catal. Sci. Technol. 2019, 9, 1189-1200. [CrossRef]

47. Lu, G.; Zheng, F.; Wang, L.; Guo, Y.; Li, X.; Cao, X.; Wang, C.; Chi, H.; Dong, Y.; Zhang, Z. Asymmetric Henry reaction catalyzed by $\mathrm{Cu}(\mathrm{II})$-based chiral amino alcohol complexes with C2-symmetry. Tetrahedron Asymmetry 2016, 27, 732-739. [CrossRef]

48. Wiedner, R.; Kothbauer, B.; Pavkov-Keller, T.; Gruber-Khadjawi, M.; Gruber, K.; Schwab, H.; Steiner, K. Improving the properties of bacterial $R$-selective hydroxynitrile lyases for industrial applications. ChemCatChem 2015, 7, 325-332. [CrossRef] 